\title{
IDENTIFICATION AND QUANTIFICATION THE AROMA COMPOUNDS FROM AUTOCHTHONOUS PLANTS WITH GC/FID SYSTEM
}

\author{
Daniela Maria, ȘANDRU ${ }^{1 *}$, Diana, STEGĂRUȘ ${ }^{2}$, Ecaterina, LENGYEL ${ }^{1}$, Ovidiu, TIȚA ${ }^{1}$ \\ ${ }^{1}$ Microbiology and Biotechnology Research Center "Lucian Blaga" University of Sibiu, Sibiu, Romania \\ ${ }^{2}$ National R\&D Institute for Cryogenic ans Isotopic Technologies - ICSI Rm. Vâlcea, Romania \\ *corresponding author: danielaraulea@yahoo.com
}

\begin{abstract}
The aims of this paper is to identify and quantify the flavor compounds that exist in plants in order to valorification in the nutritional supplements and food industry. The study was monitorising 16 different plants and the specific aromas was determined on the GC/FID system. The content esters can be reached on intervals starting from $1.0086 \mathrm{mg} / \mathrm{L}$ in Juniperus communis to $27.0172 \mathrm{mg} / \mathrm{L}$ in Teucrium chamaedrys. The superior alcohols values parameters start from $5.1209 \mathrm{mg} / \mathrm{L}$ for Melissa officinalis to $132.0837 \mathrm{mg} / \mathrm{L}$ in Teucrium chamaedrys. The aldehydes started from at minimum of $1.0218 \mathrm{mg} / \mathrm{L}$ at Centaurium erythraea and a maximum of 37.1829 at Vaccinium vitis-idaea. The terpene compounds starts from $0.0182 \mathrm{mg} / \mathrm{L}$ for Centaurium erythraea to $19.9280 \mathrm{mg} / \mathrm{L}$ at Teucrium chamaedrys. The results we obtained by this study represents the foundation for us in these bio potentially active plants in two important industries: the pharmaceutical and the food one-by obtaining nutritional supplements, liquors, extracts and tinctures.
\end{abstract}

KEY WORDS: plants with bioactive potential, flavors, GC/FID

\section{INTRODUCTION}

The traditional medicine was currently using this plant without having a really base, only for practical results. However their bioactive effects were well known without having a scientific study. A review of some local plants can provide new opportunities and developed valuable products on the market by maximizin the nutritional, antimicrobial or bioactive qualities.

The Bilberry (Vaccinium myrtillus) have a positive impact on capillaries [7].The Artichoke (Cynara scolymus) contains a polyphenols, and other bioactive compounds [14]. Chicory (Cichorium intybus) is known for his antimicrobial activity and high anthelmintics $[11,13,5]$. The Dumb (Teucrium chamaedrys) is rich in terpene compounds and glycosides [6]. The Fennel (Foeniculum vulgare), the Juniper (Juniperus communis) and the Thorn (Xanthium spinosum) is a medicinal plants rich in essential oils, phytosterols, caffeic acid, flavonoids [10]. Peppermint (Mentha) contains a significant quantity of volatile oils, tannins, flavonoids, polyphenolic substances [1,3]. Wormwood (Artemisia absinthium) is a plant with many purposes such as stimulant of gastric secretions, inflammatory, anthelmintic [4]. The Lemon balm (Melissa officinalis), St. John's Wort (Hypericum perforatum) and Oregano (Origanum vulgare) volatile oils contained are rich in compounds such as bioflavonoids [12,9]. He flavors are a wide range of chemical compounds that lead to an olfactory perception in plants $[8,2]$.The most significant is: superior alcohols, terpene compounds, bitter substances, the aldehydes and ketones, the esters, the way to dose and identify them being possible by using modern methods like gas phase chromatography.

\section{MATERIALS AND METHODS}

Plants with bioactive potentially: blueberries, artichoke, chicory, dumb, fennel, thorn, juniper, mint, cranberry, hawthorn, wormwood, willow herb, lemon balm, St.John's worth, oregano, centaury. The plants was dried and ground. The powder was homogenized in ethanol $50 \%$ for extraction of bioactive components in a ratio of $1: 10$ for 24 hours. The samples were filtered and brought to dryness. The extract was dissolved in ultrapure water 1:1. The aromatic plants profile evaluation was performed by using the GC / FID system (gas chromatograph coupled with ionisation flame). The standards used was purchased from Sigma Aldrich.

\section{RESULTS AND DISCUSSION}

Following the figure 1 there is a significant variation in the concentration of esters from the studied plants. It is noted appreciable values on Teucrium chamaedrys $27.0172 \mathrm{mg} / \mathrm{L}$ and decreased values by $17 \%$ for Vaccinium myrtillus. 


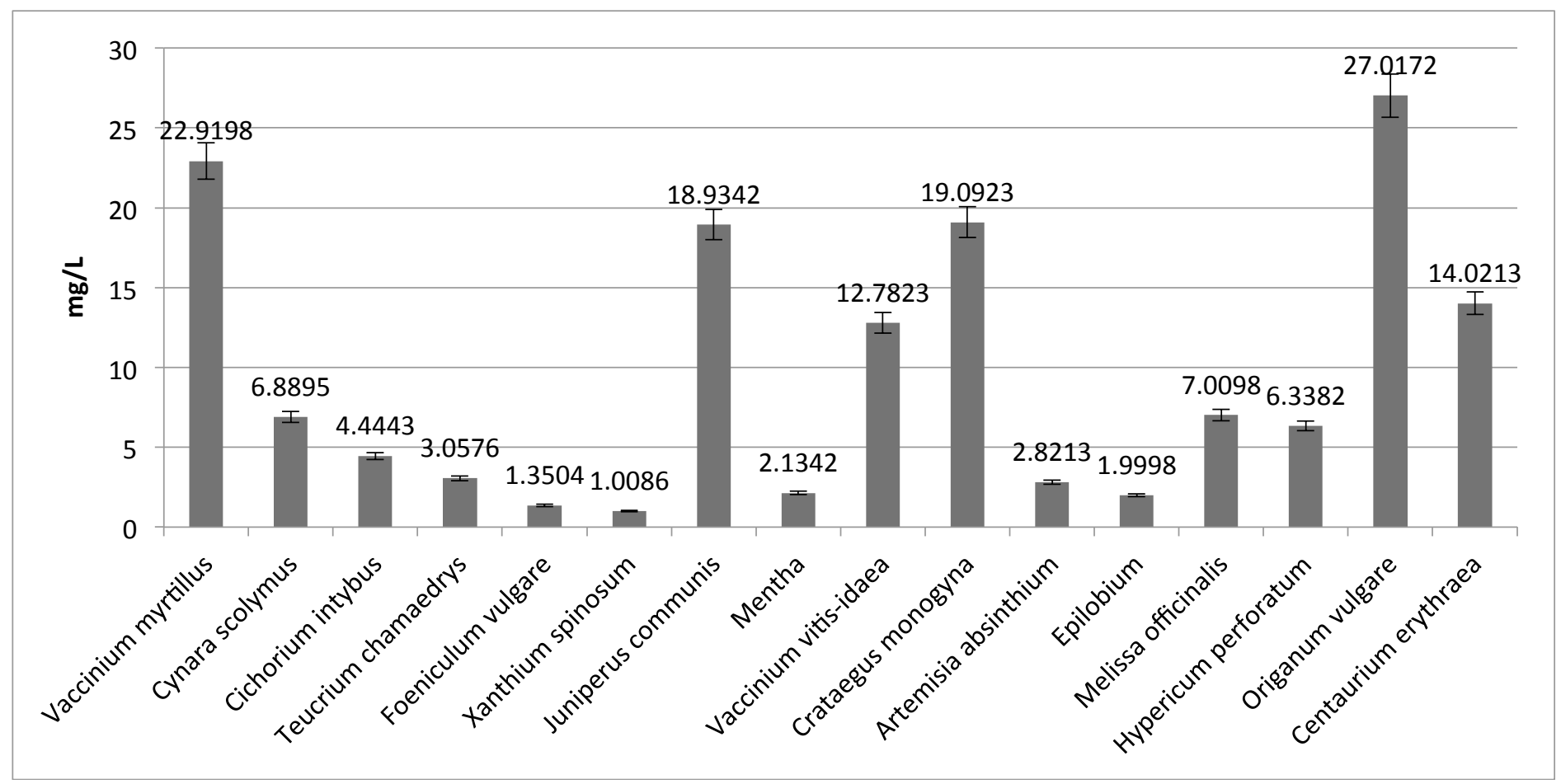

Figure 1. The identification and quantification of esters in the plants with bioactive potential

Similar values of wormwood (Artemisia absinthium) has been detected in the mint plant (Mentha) - $19.0923 \mathrm{mg} / \mathrm{L}$, respectively $18.9342 \mathrm{mg} / \mathrm{L}$. At $1.3 \mathrm{~g} / \mathrm{L}$ difference is situated the centaury (Centaurium erythraea) from the hawthorn (Crataegus monogyna); the values were in this case located at $14.0213 \mathrm{mg} / \mathrm{L}$, respectively $12.7823 \mathrm{mg} /$ L.Low levels of esters presents the chicory plant (Cichorium intybus) of 4.4443 $\mathrm{mg} / \mathrm{L}$, fennel (Foeniculum vulgare) of $3.0576 \mathrm{mg} / \mathrm{L}$, willow herb (Epilobium) of 2,8213mg / L, cranberry (Vaccinium vitis- idaea) of $2.1342 \mathrm{mg} / \mathrm{L}$. The lower limit have the following plants: lemon balm (Melissa officinalis), the thorn (Xanthium spinosum) and juniper (Juniperus communis) values are below $2 \mathrm{mg} / \mathrm{L}$, respectively $1.9998 \mathrm{mg} / \mathrm{L}, 1.3504 \mathrm{mg} / \mathrm{L}$ and $1.0086 \mathrm{mg} / \mathrm{L}$.

In the Figure 2 the dumb (Teucrium chamaedrys) has an averages of $132.0837 \mathrm{mg} / \mathrm{L}$ higher alcohols, which is the maximum value determined by this study.

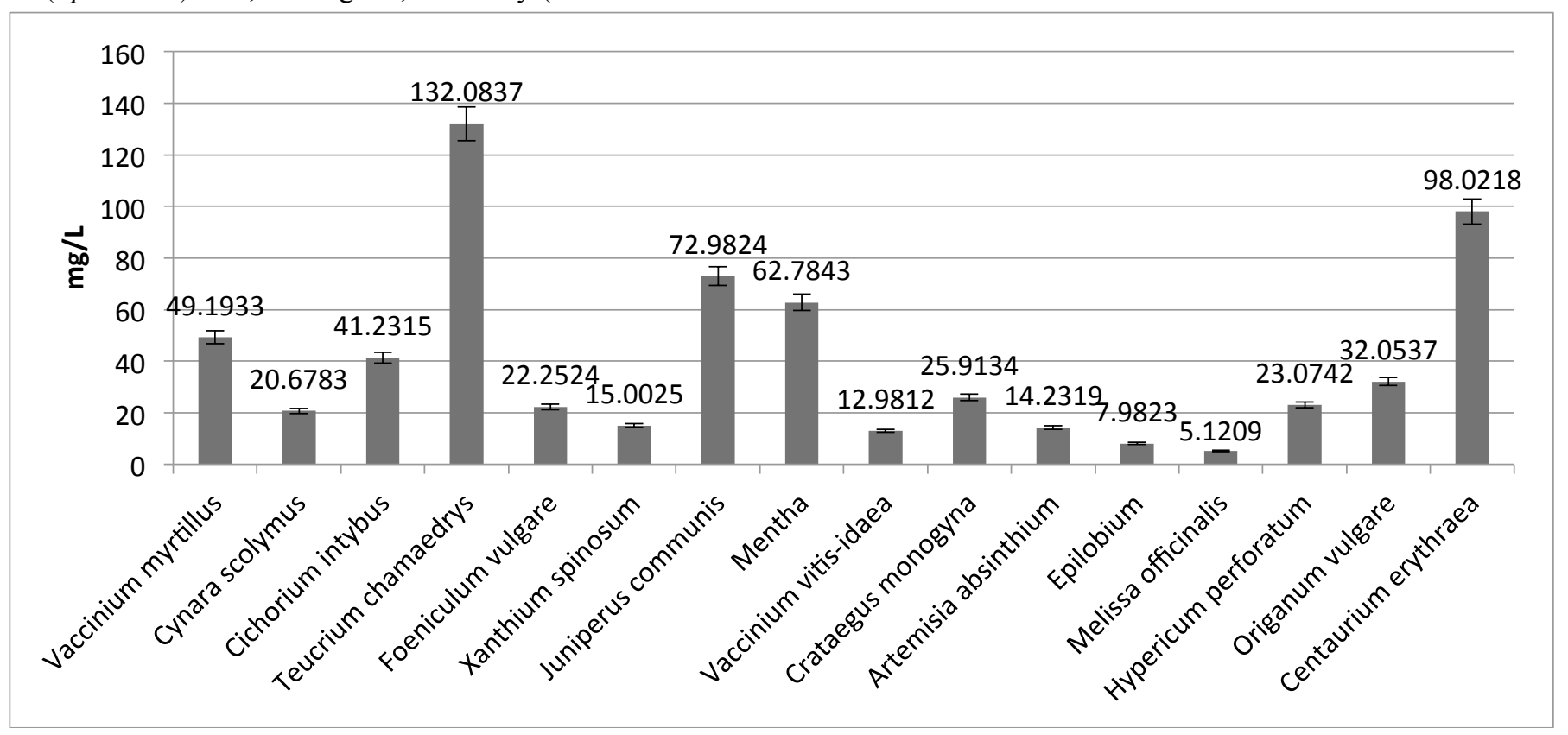

Figure 2. The identification and quantification of superior alcohols in the plants with bioactive potentially

From $30 \mathrm{mg} / \mathrm{L}$ and $50 \mathrm{mg} / \mathrm{L}$ superior alcohols has chicory (Cichorium intybus), blueberries (Vaccinium myrtillus) and oregano (Origanum vulgare); the average is being determined to $41.2315 \mathrm{mg} / \mathrm{L}, 49.1933 \mathrm{mg} / \mathrm{L}$, ie $32.0537 \mathrm{mg} / \mathrm{L}$. The lowest values are detected in the hawthorn (Crataegus monogyna) 25,9134 mg / L, St. John's wort (Hypericum perforatum) 23,0742 $\mathrm{mg} / \mathrm{L}$ and fennel (Foeniculum vulgare) with $22.2524 \mathrm{mg} / \mathrm{L}$.
The aldehydes (Figure 3 ) is an interesting segment for complet the bioactive profile on studied plants. The resulting values have a minimum of $1.0208 \mathrm{mg} / \mathrm{L}$ for centaury (Centaurium erythraea), $1.0723 \mathrm{mg} / \mathrm{L}$ for lemon balm (Melissa officinalis)

Analyzing the results can be seen that four plant extracts sets of the aldehydes values- between $10 \mathrm{mg} / \mathrm{L}$ and $20 \mathrm{mg} / \mathrm{L}$. Those are: hawthorn (Crataegus monogyna) with $17.9231 \mathrm{mg} / \mathrm{L}$, 
fennel (Foeniculum vulgare) with 14.6497, St. John's wort (Hypericum perforatum) with $14.0271 \mathrm{mg} / \mathrm{L}$, dumb (Teucrium chamaedrys) 11, $1098 \mathrm{mg} / \mathrm{L}$. Aldehyde values between $5 \mathrm{mg} /$ $\mathrm{L}$ and $10 \mathrm{mg} / \mathrm{L}$ were detected in oregano (Origanum vulgare) to $9.0484 \mathrm{mg} / \mathrm{L}$, thorn (Xanthium spinosum) to $7.4784 \mathrm{mg} / \mathrm{L}$, willow herb (Epilobium) of $5.1989 \mathrm{mg} / \mathrm{L}$. The lowest values of aldehydes (1.0723 mg / L respectively $1.0218 \mathrm{mg} / \mathrm{L}$ ) are detected at centaury (Centaurium erythraea) and lemon balm (Melissa officinalis). characterize the plants. In Figure 4 can be seen that the values determined subunit $0.0182 \mathrm{mg} / \mathrm{L}$ at centaury (Centaurium erythraea), $0.1204 \mathrm{mg} / \mathrm{L}$ artichoke (Cynara scolymus), 0.1325 $\mathrm{mg} / \mathrm{L}$ at the willow herb (Epilobium), tens dumb (Teucrium chamaedrys: $19.9280 \mathrm{mg} / \mathrm{L}$ ) and peppermint (Mentha: $17.9785 \mathrm{mg} / \mathrm{L}$ ). Terpene compounds values from $10 \mathrm{mg} / \mathrm{L}$ and $20 \mathrm{mg} / \mathrm{L}$ are seen in fennel (Foeniculum vulgare) with $16.2908 \mathrm{mg} / \mathrm{L}$, a thorn (Xanthium spinosum) with $15.9213 \mathrm{mg}$ / L, or juniper (Juniperus communis) with $13.4538 \mathrm{mg} / \mathrm{L}$.

The Terpene compound is built in plants in different forms.

Due to specific reactions presents a range of flavors that can

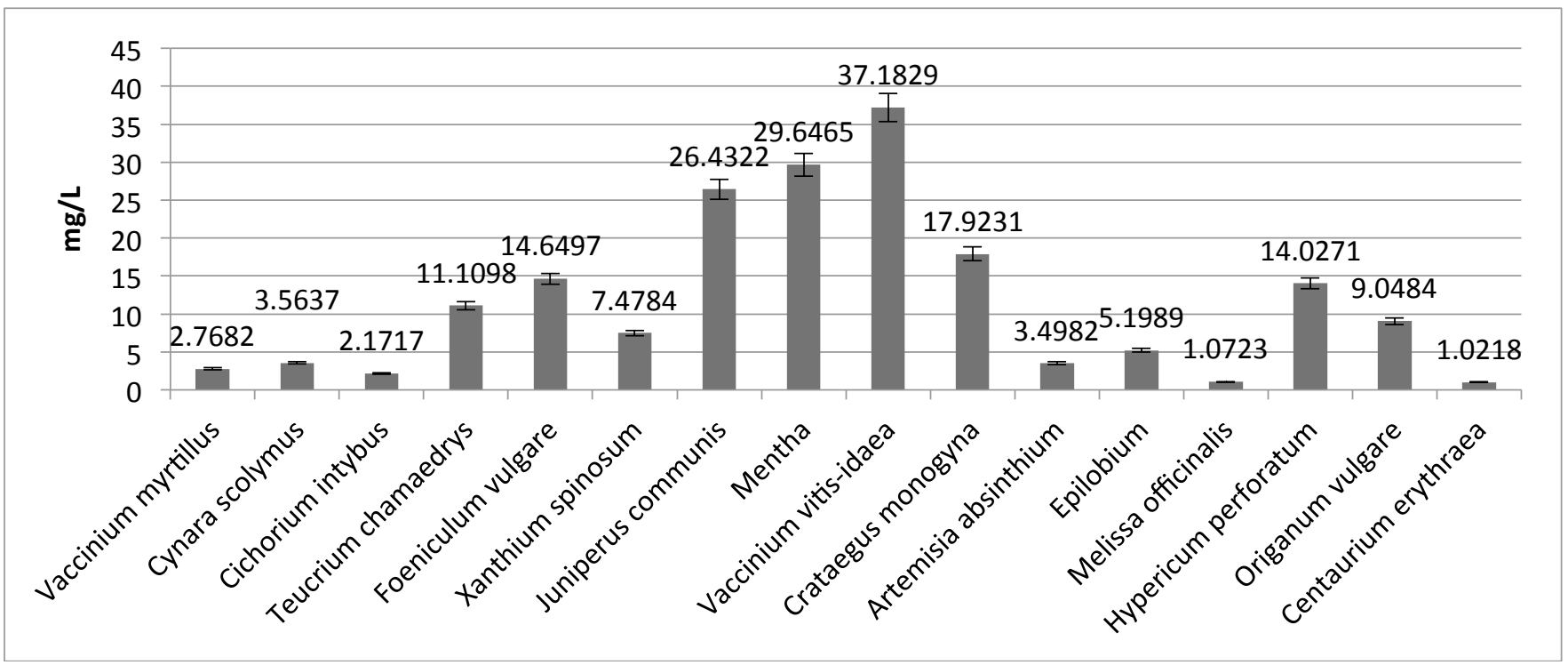

Figure 3. The identification and quantification of aldehydes in the plants with bioactive potentially

Other plants such as chicory, blueberries, cranberries and lemon balm have accumulated terpene compounds values from $4 \mathrm{mg} / \mathrm{L}$ to $7 \mathrm{mg} / \mathrm{L}$. The Chicory plant (Cichorium intybus) reaches values of $6.2121 \mathrm{mg} / \mathrm{L}$, the bilberry plant (Vaccinium myrtillus) have a rate of $5.7854 \mathrm{mg} / \mathrm{L}$ and the cranberry plant (Vaccinium vitis-idaea) to $4.1851 \mathrm{mg} / \mathrm{L}$.
The lemon balm (Melissa officinalis) accumulates $4.0924 \mathrm{mg} /$ $\mathrm{L}$ terpene compounds. Under these values we have wormwood (Artemisia absinthium) with $2.9143 \mathrm{mg} / \mathrm{L}$ terpene compounds, St. John's Wort (Hypericum perforatum), hawthorn (Crataegus monogyna) with values of $30 \%-31 \%$ lower than sage and oregano (Origanum vulgare) with values of $1.5050 \mathrm{mg} / \mathrm{L}$.

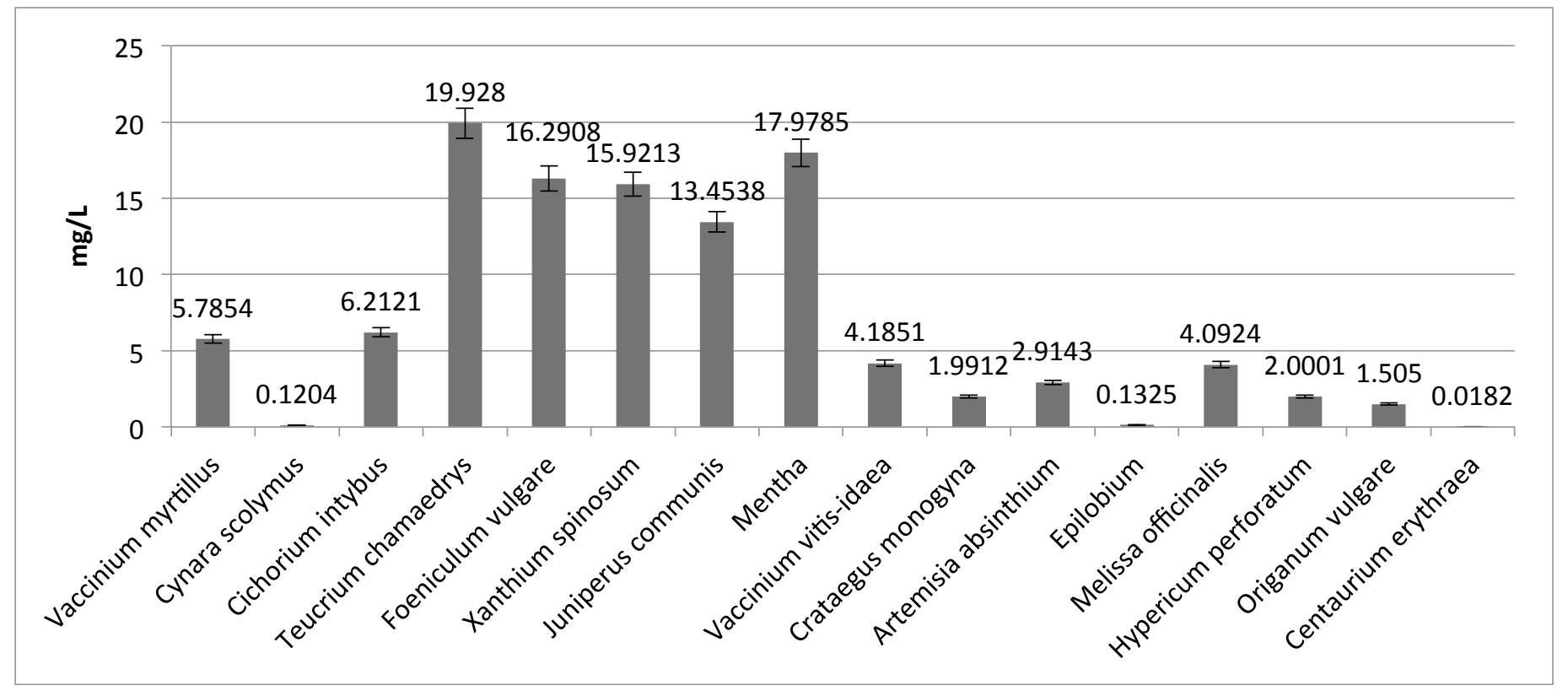

Figure 4. The identification and quantification of terpenes compounds in the plants with bioactive potentially 


\section{CONCLUSION}

Every single plant we used in this study has amounts of bioactive compounds that contribute to their use in food and pharmaceutical industries.

It was detected that the lowest amounts of esters were found in juniper (Juniperus communis) and the maximum in dumb (Teucrium chamaedrys). The intermediate values can be seen on artichoke (Cynara scolymus), oregano (Origanum vulgare), St. John's wort (Hypericum perforatum).

Superior alcohols lowest value was detected in lemon balm (Melissa officinalis) and the maximum values- above $100 \mathrm{mg} /$ L dumb (Teucrium chamaedrys).

$33 \%$ loweset ranges is the values identified in centaury (Centaurium erythraea) followed by juniper (Juniperus communis) and peppermint (Mentha).

The aldehydes values ranges below $50 \mathrm{mg} / \mathrm{L}$-that is a minimum on centaury (Centaurium erythraea) of the unit and a maximum of a few tens on cranberry (Vaccinium vitis-idaea).

The terpenes compounds are based on much lower values for centaury (Centaurium erythraea) and up to values of tens for dumb (Teucrium chamaedrys).

\section{REFERENCES}

1. Adham A.N., Comparative extraction methods, phytochemical constituents, fluorescence analysis and HPLC validation of rosmarinic acid content in Mentha piperita, Mentha longifolia and Osimum basilicum, Journal of Pharmacognosy and Phytochemistry, 2015; Volume 3, Issue 6, Part C, Pg 130-139.

2. Bucur L., Ţarălungă G., Schroder V., The betalains content and antioxidant capacity of red beet (beta vulgarisl. subsp. vulgaris) root, Farmacia, 2016; vol. 64, 2, 198-201.

3. Calderone A., Castagnoli L. \& Cesareni G., Mentha: a resource for browsing integrated protein-interaction networks, Nature Methods 10, 2013; 690-691.
4. Luyckx V. A., Naicker S., Acute kidney injury associated with the use of traditional medicines Nature Reviews Nephrology 4, 2008; 664-671.

5. Mocan A., Vlase L., Arsene A.L., Vodnar D., Bischin C., Silaghi-Dumitrescu R., Crișan G., HPLC/MS analysis of caffeic and chlorogenic acids from three romanian veronica species and their antioxidant and antimicrobial properties, Farmacia, 2015; vol. 63(6): 890-896.

6. Nencini C., Galluzzi P., Francesco Pippi, Andrea Menchiari, Lucia Micheli, Hepatotoxicity of Teucrium chamaedrys L. decoction: role of difference in the harvesting area and preparation method, Indian J Pharmacol, 2014; 46(2): 181-184.

7. Oancea S., Grosu C., Effect of Vaccinium myrtillus anthocyanin extract on lipid oxidation in cod liver oil, Rom. Biotech. Lett, 2013; 18(1): 7897-7903.

8. Oprea E., Manolescu B.N., Fărcăşanu I.C., Mladin P., Mihele D., Studies concerning antioxidant and hypoglycaemic activity of Aronia melanocarpa fruits, Farmacia, 2014; 62(2): 254-263.

9. Quave C. L. \& Pieroni A., A reservoir of ethnobotanical knowledge informs resilient food security and health strategies in the Balkans, Nature Plants 1, 2015, 14021.

10. Quiroga, R., Meneses L. and Bussmann W.R., Medicinal ethnobotany in Huacareta (Chuquisaca, Bolivia), Journal of Ethnobiology and Ethnomedicine, 2012; 8:29.

11. Street A.R., Sidana J., and Prinsloo G., Cichorium intybus: Traditional Uses, Phytochemistry, Pharmacology and Toxicology, Evidence-Based Complementary and Alternative Medicine, 2013; Volume 2013 Article ID 579319, 13 pages http://dx.doi.org/10.1155/2013/579319.

12. Tian J., Zhang F., Wang H., Antidepressant-like activity of adhyperforin, a novel constituent of Hypericum perforatum L. Scientific Reports 4, 2014; 5632.

13. Wang Q. and Cui J., "Perspectives and utilization technologies of chicory (Cichorium intybus L.): a review," African Journal of Biotechnology, 2011; 10(11): 19661977.

14. Wider B., Pittler M.H., Thompson-Coon J., Ernst E., Artichoke leaf extract for treating hypercholesterolaemia, Cochrane Database Syst Rev. 2013. 